\title{
Obesity and fractures
}

\author{
Obesidade e fraturas
}

Melissa Orlandin Premaor', Fabio Vasconcellos Comim', Juliet E. Compston²

${ }^{1}$ Department of Clinical Medicine, Health Sciences Center, Federal University of Santa Maria (UFSM), Santa Maria, RG, Brazil

${ }^{2}$ Cambridge Biomedical Campus, Cambridge, United Kingdom

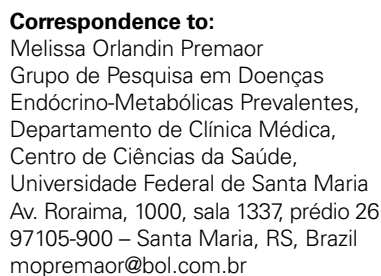

Received on Feb/12/2014 Accepted on May/19/2014

DOI: 10.1590/0004-2730000003274

\begin{abstract}
Until recently obesity was believed to be protective against fractures. However, a report from a Fracture Liaison Clinic in the UK (2010) reported a surprisingly high proportion of obese postmenopausal women attending the clinic with fractures, and in the GLOW study (2011), a similar prevalence and incidence of fractures in obese and non-obese postmenopausal women was observed. Subsequently, other studies have demonstrated the importance of obesity in the epidemiology of fractures. Obese women are at increased risk of fracture in ankle, leg, humerus, and vertebral column and at lower risk of wrist, hip and pelvis fracture when compared to non-obese women. In men, it has been reported that multiple rib fractures are associated with obesity. Furthermore, falls appear to play an important role in the pathogenesis of fractures in obese subjects. Regarding hip fracture and major fractures, the FRAX algorithm has proven to be a useful predictor in obese individuals. Obese people are less likely to receive bone protective treatment; they have a longer hospital stay and a lower quality of life both before and after fracture. Moreover, the efficacy of antiresorptive therapies is not well established in obese people. The latter is a field for future research. Arq Bras Endocrinol Metab. 2014;58(5):470-7
\end{abstract}

\section{Keywords}

Obesity; fractures; osteoporosis; osteopenia

\section{RESUMO}

Acreditava-se que pessoas obesas estavam protegidas contra fraturas. No entanto, um estudo realizado no Reino Unido (2010) encontrou uma proporção surpreendentemente alta de obesidade entre as mulheres na pós-menopausa que se consultaram em uma Clínica de Fraturas Ósseas. Da mesma maneira, o estudo GLOW (2011) observou prevalência e incidência semeIhantes de fraturas em mulheres na pós-menopausa obesas e não obesas. Posteriormente, vários outros estudos têm demonstrado a importância da obesidade na epidemiologia de fraturas. Mulheres obesas têm maior risco de fratura no tornozelo, na perna, no úmero e na coluna vertebral e têm menor risco de fratura de punho, quadril e pelve quando comparadas às mulheres não obesas. A associação entre fraturas múltiplas de costelas e obesidade foi descrita em homens. Além disso, as quedas parecem desempenhar um papel importante na patogênese de fraturas em pacientes obesos. O algoritmo FRAX parece ser uma ferramenta útil na predição do risco de fraturas em indivíduos obesos. Indivíduos obesos são menos propensos a receber tratamento preventivo para as fraturas ósseas e, quando sofrem uma fratura óssea, sua internação costuma ser mais longa do que a internação de indivíduos magros. A qualidade de vida dos indivíduos obesos é menor antes e depois da fratura. Não obstante, a eficácia de terapias antirreabsorção não está bem estabelecida em pessoas obesas. Este último é um campo para pesquisas futuras. Arq Bras Endocrinol Metab. 2014;58(5):470-7

\section{Descritores}

Obesidade; fraturas ósseas; osteoporose, osteopenia

\section{INTRODUCTION}

$\mathrm{O}$ besity and bone fractures are common disorders associated with high morbi-mortality and elevated public health costs worldwide (1-3).
Until recently, it was generally believed that obesity was protective against fracture. This misconception was in part conceived from the positive correlation between bone mineral density (BMD) and body mass index 
(BMI) $(4,5)$, and the lower incidence of hip fractures in obese subjects (6). In 2010, a study from a Fracture Liaison Service in the United Kingdom reported for the first time an unexpectedly high prevalence of obesity $(27 \%)$ in postmenopausal women presenting with a fragility fracture (7).

Confirmation that obesity was not a protective factor against low trauma fractures was reported in 2011, when results of the Global Study of Osteoporosis in Women (GLOW) were presented (8). This multicentre prospective observational study, conducted in 60,393 postmenopausal women, showed a comparable prevalence and incidence of fractures in normal weight and obese women (8).

Subsequently, other investigators have studied the impact of obesity on bone mass and the risk of fracture (9-14). The present review focuses on the epidemiology, risk factors, diagnosis, and management of fractures in obese postmenopausal women and older men.

\section{FRACTURE EPIDEMIOLOGY - OBESITY IS NOT PROTECTIVE}

Evidence from the literature supported the initial findings of the Fracture Liaison Service study from Cambridge UK (7). Ong and cols. evaluated 4,288 men and women who attended the Fracture Liaison Service of East Midlands Trauma Centre in Nottingham, UK and found a prevalence of obesity of $30 \%$ (15). As previously mentioned, in the GLOW study no statistically significant differences were seen in occurrence of fractures in obese and non-obese individuals, respectively $22.2 \%$ versus $22.7 \%$ for prevalence and $6.2 \%$ versus $6.6 \%$ for incidence (8).

Interestingly, obese men are not protected against hip fracture, as is seen in women. The Multicentre Osteoporotic Fracture in Men Study (MrOS), conducted in the USA, included 5,995 males aged 65 years or more, and found that a higher BMI was associated with increased fracture risk (16). In this study, $62 \%$ of hip fractures and $68 \%$ of non-vertebral fractures were seen in overweight and obese men (16). Similarly, analysis of the National Health and Nutrition Examination Survey I (NHANES) in 2012, reported that obesity was present in $58 \%$ of men with fracture (10). In the North American multicentre Study of Osteoporotic Fractures (SOF), which followed 7,978 women aged 65 or more years of age for 11.3 years, the incidence of non-vertebral fractures was $37.5 \%$ in obese women versus $44.3 \%$ in non-obese women (17).
In the Million Women Study, in which 925,345 women from the UK were followed for 6.2 years or longer to assess the effects of hormone replacement therapy on diverse endpoints, the incidence of hip fractures in obese and overweight individuals was also remarkable. Thus, despite the inverse correlation of weight and fractures observed, a high proportion (40\%) of women with hip fracture were overweight or obese (18). These results are in agreement with the aforementioned analysis of NHANES, which demonstrated that $46 \%$ of hip fractures occurred in women who were obese or overweight (10).

Results from meta-analysis have been used to describe the relationship between bone density and BMI. De Laet and cols. identified an inverse relation (nonlinear) between BMD and incidence of fractures (19). They observed a higher risk of fractures in subjects with BMI under $20 \mathrm{~kg} / \mathrm{m}^{2}$ but only small increments above BMI of $25 \mathrm{~kg} / \mathrm{m}^{2}$ (19). Interestingly, in the same study the relationship between BMI and non-hip fractures disappeared (19). Complementary data came from the work of Johansson and cols. including 398,610 women from 25 prospective studies $(80 \%$ which were population-based) (20). This study found a small, but progressive risk for fractures after adjustment for BMD. In this meta-analysis, an increase of $1 \mathrm{~kg} / \mathrm{m}^{2}$ above a BMI of $25 \mathrm{~kg} / \mathrm{m}^{2}$ corresponded to an increase of $1 \%$ in the risk of fracture [HR 1.01 (95\%CI 1.01,1.02)] (20).

\section{SITE OF FRACTURE}

Several studies have demonstrated that the relationship between BMI and fracture is site-specific $(8,11,12,14,16,21,22)$. While obesity is protective against hip fracture in women, it is associated with higher risk of fractures at some other sites. One reason for the lower frequency of hip fracture may be related to the presence of fat tissue (padding) surrounding the pelvis and the femur that reduces the impact of falling (23). On the other hand, obese subjects are at higher risk of falling and less well able to protect themselves against a fall (24-26). Falls in individuals who are overweight or obese are more likely to occur backwards or sidewards, in contrast to forward falls in leaner individuals (27). Exaggeration of introversion and extroversion of the ankle and lower leg in obese subjects may be also responsible for a higher prevalence of fractures at these sites. Moreover, increased body weight can also promote an increase in the pressure (stress) in some sites, predisposing to fracture (28). 
The commonest sites of fractures in obese subjects are shown in table 1 . As can be seen, obese women experience more fractures in the ankle, leg, humerus, and vertebral column and fewer in the wrist, hip and pelvis. In men, it has been reported that multiple rib fractures are associated with obesity. In a population based-study in Spain, analysing 139,419 men aged 65 years or over, hip fractures in obese individuals were significantly less common than in non-obese men (11). These data are in contrast to those of Nielson and cols., who found an increased incidence of hip fracture in men after adjustment for BMD (16).

Table 1. Fracture sites and their association with obesity in women and men

\begin{tabular}{lcc}
\hline Fracture site & Obese women & Obese men \\
\hline Ankle & $\begin{array}{c}\text { Positively associated } \\
(64,65)\end{array}$ & $\begin{array}{c}\text { Positively associated } \\
(16,65)\end{array}$ \\
Lower leg & $\begin{array}{c}\text { Positively associated (66) } \\
\text { Positively associated } \\
(8,66)\end{array}$ & $\begin{array}{c}\text { Positively associated (16) } \\
\text { Upper leg }\end{array}$ \\
Proximal humerus & $\begin{array}{c}\text { Positively associated } \\
(12,22)\end{array}$ & Null (11) \\
Multiple rib & Null (12) & Positively associated (11) \\
Vertebral & Positively associated & Negatively associated (11) \\
Wrist & $(9,13,14,67)$ & \\
Hip & Negatively associated (17) & Negatively associated (11) \\
Pelvis & Negatively associated (12) & Positively associated after \\
& Negatively associated (12) & Negatively associated (11) \\
\hline
\end{tabular}

* Negatively associated with hip fractures without BMD correction (11); however, in the MrOS study hip fracture was positively associated with obesity after BMD adjustments (16).

\section{RISK FACTORS FOR FRACTURE}

Obese and non-obese individuals share similar risk factors for fractures. Thus, age, history of previous fracture, family history of fracture (maternal), and use of glucocorticoids increase the risk of fractures in obese women (8). In addition to this, falls play an important role in obese individuals as does reduced physical mobility $(8,16)$.

Obesity-associated comorbidities such as diabetes (Table 2) that also predispose to fractures have been identified as risk factors for fractures in obese women (8). The association of fractures with poor or fair general health and co-morbidities in women (8) and with the narrow walk pace (16) in men also suggests that, these individuals share some aspects of the frailty of elderly people.
The progressive increment of BMD with $\mathrm{BMI}$ is well established; however it might be not strong enough to compensate for the increased mechanical stresses on the skeleton. Premaor and cols. investigated the relationship between BMD and fractures in obese women (17). In this study, the risk of non-vertebral fractures increased $60 \%$ for each corresponding reduction of one standard deviation (SD) of BMD in the femoral neck (FN). Moreover, overweight or obese women with fractures had a mean FN BMD T-score of - 1.5 (CI95\% 1.4, 1.6), suggesting that fractures occurred at a higher BMD than in lean women (17).

The risk factors of fractures in obese people are described at table 2 .

Table 2. Risk factors associated with fractures in obese subjects $(8,16,17)$

\begin{tabular}{ll}
\hline \multicolumn{1}{c}{ Risk factor } \\
\hline \multicolumn{1}{c}{ Reported in women } & \multicolumn{1}{c}{ Reported in men } \\
\hline Age & Previous fracture \\
Previous fracture & \\
Maternal hip fracture & \\
Low BMD* & Mobility limitations \\
Use of arms to assist stand from a & Difficulty climbing 10 steps \\
sitting position & Difficulty walking two blocks \\
& \\
Falls & \\
Two or more in the previous year & Narrow walk pace \\
Poor or fair general health & \\
Glucocorticoid use & \\
Comorbidities & \\
Asthma & \\
Emphysema & \\
Diabetes with insulin use & \\
\hline * OR 1.6 (Cl 95\% 1.5, 1.8) per $1 \mathrm{SD}$ decrease at femoral neck (17).
\end{tabular}

\section{FRACTURE RISK ASSESSMENT}

The World Health Organization (WHO) supports the estimation of fracture probabilityusing the $\mathrm{FRAX}^{\circledR}$ algorithm (29). This tool defines the 10 -year probability for hip or other major fracture (clinical vertebral, forearm, hip and humerus) in an individual and it is freely available on the web (http://www.shef.ac.uk/ FRAX/). Because BMD and BMI are included in the algorithm, its applicability to obese individuals might be questioned $(30,31)$.

It is important to emphasize that changes in the amount and distribution of body fat are likely to affect both accuracy and precision of BMD (32). However, it 
is not known how much of this error would affect the interpretation of the DXA results. Studies that access the real effect of fat on the BMD measured by DXA are difficult to conduct. When lard was placed above the hip and the spine of lean subjects, there was a small increase in BMD at the hip (1.6\%) and a small decrease in BMD at the spine $(0.7 \%)(33)$. In a recent paper, $\mathrm{Yu}$ and cols. demonstrated that quantitative computed tomography (QCT) was superior to DXA in the evaluation of bone mass in obese subjects after bariatric surgery (34). In the latter, the correlation between the two methods was only moderate and BMD measurements at hip were overestimated by DXA (34).

The ability of FRAX to predict fractures in obese postmenopausal women was addressed in a recent study (35). In spite of a lower estimated probability of fractures in obese than in non-obese women with fracture, the accuracy of FRAX was similar in both groups. In addition, in the same study, the net benefit (analysis that balances the false positives and false negatives employing a decision curve using clinical practice models) had a satisfactory performance in both obese and non-obese women (35). For hip fractures, FRAX scores which included BMD in obese subjects were superior to FRAX scores without BMD (35). It is important to note that FRAX, although useful in obese women, has not been adequately studied in situations where the BMI surpasses $40 \mathrm{~kg} / \mathrm{m}^{2}$ and the Internet tool of FRAX accepts the insertion of a maximum weight of $125 \mathrm{~kg}$ for calculation of the risk of fracture.

\section{BONE AND FAT CROSSTALK}

Although the association between obesity and fractures appears to be a paradox at first sight, there has been some progress in the understanding of the crosstalk between the bone tissue and the adipose tissue. The apparent ambiguity may be partly linked to the welldocumented relationships between oestrogens and obesity. Obese post-menopausal women tend to have higher serum levels of oestrogen than lean post-menopausal women $(4,5)$. These findings explain in part the high bone mass found in association with higher BMI. Nevertheless, oestrogen is not the only factor regulating bone mass and several factors may affect both bone and fat mass: both adipose tissue and bone cells produce factors that affect each other.

Adiponectin is a molecule produced by adipocytes that appears to have a deleterious effect on bone $(5,28)$.
Although adiponectin is inversely related to BMI, it appears to be a marker of a disrupted adaptive response in overweight subjects $(5,28)$. In the Health Aging and Body Composition Study, serum levels of adiponectin were significantly higher in overweight women with fractures when compared with overweight women without fractures (36). Another important factor is leptin which interferes with bone metabolism through complex mechanisms $(36,37)$. Leptin appears to act by two seemingly contradictory mechanisms. Individuals with high serum levels of leptin have increased bone mineral density as measured by DXA (36). However, leptin acts via the central nervous system to decrease bone formation. This latter action appears to be mediated by a decreased production of serotonin in the hypothalamic neurons (37). Moreover, adipose tissue also produces inflammatory cytokines, such as interleukin 6 (IL6) that may negatively interfere with the balance between bone resorption and formation $(5,28)$.

Osteocalcin is a molecule secreted by the osteoblasts (38). This hormone regulates insulin secretion, insulin sensitivity and energy expenditure $(37,38)$. Insulin acts directly on osteoblasts via insulin receptors to increase the production of undercarboxylated osteocalcin, resulting in increased insulin production by the pancreas and increased insulin sensitivity. Insulin also reduces the production of osteoprotegerin (OPG), leading to increased bone resorption and subsequent decarboxylation of osteocalcin (38).

Finally, peroxisome proliferator-activated receptor gamma $(\operatorname{PPAR} \gamma)$ is known to be associated with the regulation of both bone mass and fat (39), increasing the commitment of pluripotent stem to adipocytes and inhibiting commitment to the osteoblast linage. The PPAR $y$ actions are well exemplified through their agonists, the thiazolidinediones. They decrease insulin resistance while negatively affecting bone mass and increasing the risk of fractures (39).

\section{MANAGEMENT}

One key question regarding the management of obese individuals and fractures is whether weight reduction may be beneficial. Although a reduction in BMI improves many clinical outcomes in obesity, weight loss has been associated with an increase in fractures in men and women (40-42). Thus, both voluntary and involuntary weight reduction is associated with increased risk (43). It is still uncertain whether supplementa- 
tion of calcium, vitamin $\mathrm{D}$, proteins and other nutrients during a restriction diet can prevent loss of bone mass, given the heterogeneity of many different studies including only a small number of patients, short time duration and several endpoints (including substitutes as BMD). A concomitant physical exercise program may attenuate bone loss during caloric restriction $(44,45)$; however, no study has adequately analysed the impact of exercise and diet on the incidence of fractures (46).

Although non-pharmacological measures such as cessation of smoking, avoidance of alcohol excess, and regular weight bearing exercises have not been evaluated for their impact on fractures, they should be advised by the doctor. It is particularly important to perform assessment of the risk of falls and institute preventive measures where appropriate: as discussed previously in this review, falls play an important role in the development of fractures in obese subjects.

Currently, vitamin D is the only drug recognized to reduce the risk of falls (47) and supplementation of this vitamin may be beneficial given the reports of lower serum 25-hydroxyvitamin D in obese persons, in whom higher doses are often required to achieve adequate serum levels of 25-hydroxyvitamin $\mathrm{D}$ (48).

It is not known if pharmacological therapy is effective in reducing fractures in obese individuals. The majority of clinical trials that evaluated the efficacy of these drugs in fracture prevention included only a small number of obese subjects and most of those included had a low BMD, limiting the ability to extrapolate results to most obese individuals. Another important issue regarding pharmacotherapy in obese individuals is the higher number of patients with fracture who are not treated in comparison to those who are not overweight. In the GLOW study, only $27 \%$ of obese women with incident fracture received bone protective therapy, a minor proportion compared with non-obese (41\%) (8). Factors contributing to non-treatment may be related to the perception that fractures in obese are not related to bone frailty as well as the uncertainties regarding the efficacy of drug therapy.

A greater reduction in vertebral fractures in women with BMI $\geq 25 \mathrm{~kg} / \mathrm{m}^{2}$ than in women with $\mathrm{BMI}<25$ $\mathrm{kg} / \mathrm{m}^{2}$ was reported with the use of annual infusions of $5 \mathrm{mg}$ of zoledronic acid in the Health Outcomes and Reduced Incidence with Zoledronic acid Once Yearly (HORIZON) study (49). In this study, postmenopausal women were followed for 3 years; no differences were observed between obese and overweight/ obese women in non-vertebral fracture reduction (49). Another bisphosphonate, clodronate, was shown to decrease non-vertebral fractures in postmenopausal women not selected on the basis of fracture and BMD (50). The reduction of these fractures varied according to BMI as follows: $\mathrm{BMI} \leq 2 \mathrm{l} \mathrm{kg} / \mathrm{m}^{2}-40 \%$ [HR $0.60(95 \%$ CI $0.45,0.81)$ ], BMI $\geq 26 \mathrm{~kg} / \mathrm{m}^{2}$ to < $30 \mathrm{~kg} / \mathrm{m}^{2}-25 \%$ [HR 0.75 (95\%CI 0.62, 0.92)], and $\mathrm{BMI} \geq 30 \mathrm{~kg} / \mathrm{m}^{2}-10 \%$ [HR 0.90 (95\%CI $\left.0.69,1.17\right)$ ] (50). Finally, denosumab was effective in reducing the incidence of vertebral fractures regardless of BMI, although a sub-group analysis of this study - Fracture Reduction Evaluation of Denosumab in Osteoporosis Every 6 Months (FREEDOM), did not demonstrate significant protection against non-vertebral fractures in overweight or obese women (51).

\section{FRACTURE MORBIDITY AND MORTALITY IN OBESE INDIVIDUALS}

Studies that have evaluated the recovery of obese individuals after fracture demonstrated an increased morbidity. Thus, obese subjects experienced a higher prevalence of co-morbidities, increased risk of non-union of fractures, more post-operative complications and longer time for recovery (52-56). However, these studies included both low-impact and high-impact fractures.

In the GLOW study, obese women with fractures had a longer hospital stay than non-obese women, even after adjustments for age, co-morbidities and type of fractures (median, 6 vs. 5 days; $\mathrm{p}=0.017$ ) (21). In the same study, the physical function and vitality were assessed through the quality of life questionnaires SF-36 and EuroQol EQ-5D tool. The obtained scores were worse in obese than non-obese woman before and after fracture (2l).

There is a lack of data regarding mortality of obese individuals after low-impact bone fractures. Analyzing the population health database from the family strategy program SIDIAP ${ }^{\circledR}$ (Catalunya, Spain), Prieto-Alhambra and cols., described longer survival of overweight and obese individuals than normal weight subjects (18.5 to $<25 \mathrm{~kg} / \mathrm{m}^{2}$ ) after incident clinical fracture (57). This observation is consistent with other reports of the "obesity paradox" in conditions such as congestive cardiac failure, chronic renal insufficiency and chronic obstructive pulmonary disease (58-61). The theory behind this obesity paradox is that some harmful risk factors such as obesity are not deleterious in specific conditions (e.g. 
elderly subjects or individuals with chronic diseases) but are associated with better survival. Obesity seemed not to be deleterious in a population cohort of Olmsted Country (Minessota, US), where the risk of cardiac and non-cardiac post-operative complications was similar among overweight, obese patients and subjects within the normal weight range $(62,63)$.

\section{CONCLUSION}

The proportion of fractures occurring in obese people is considerable, and is likely to increase with the progressive rise in obesity in the world population. Subjects with higher BMI are at higher risk of fractures at some sites such as the humerus, lower leg and ankle. This may be at least in part related to the increased risk of falls and their different pattern when compared to non-obese individuals. Clinical risk factors for fracture are similar in obese and non-obese subjects. Although fractures in the obese population occur at a higher BMD than in non-obese subjects, the inclusion of BMD in the algorithm FRAX is superior to FRAX without the inclusion of BMD in the prediction of hip fractures in obese individuals. For major osteoporotic fracture prediction, the FRAX tool may be used with or without BMD.

Mortality in obese people after fracture is less than that of normal weight subjects with fracture although longer hospitalization after fracture and lower quality of life in these individuals both before and after fracture have been documented. Of note, the proportion of obese subjects undergoing preventive treatment for fractures is low, and inferior to that in the non-obese. The reasons for these differences should be established in further studies; in addition, the efficacy of bone protective therapy in obese individuals remains to be established.

Disclosures: Melissa Orlandin Premaor has grants from the Conselho Nacional de Desenvolvimento Científico e Tecnológico (CNPq) [Bolsista de Produtividade de Pesquisa II, 472211/2013-7 and Edital Universal, 307057/2013-5]. Fabio Comim has grants from the Federal University of Santa Maria (ARD/CCS 2012, ARD/CCS 2013, and UFSM - FIPE/CCS 2013). All authors state that they have no conflict of interest regarding this manuscript.

\section{REFERENCES}

1. Finucane MM, Stevens GA, Cowan MJ, Danaei G, Lin JK, Paciorek $\mathrm{CJ}$, et al. National, regional, and global trends in body-mass index since 1980: systematic analysis of health examination surveys and epidemiological studies with 960 country-years and 9.1 million participants. Lancet. 2011;377(9765):557-67.

2. Guh DP, Zhang W, Bansback N, Amarsi Z, Birmingham CL, Anis $\mathrm{AH}$. The incidence of co-morbidities related to obesity and overweight: a systematic review and meta-analysis. BMC public health. 2009;9:88.

3. Hernlund E, Svedbom A, Ivergard M, Compston J, Cooper C, Stenmark $\mathrm{J}$, et al. Osteoporosis in the European Union: medical management, epidemiology and economic burden. A report prepared in collaboration with the International Osteoporosis Foundation (IOF) and the European Federation of Pharmaceutical Industry Associations (EFPIA). Arch Osteoporos. 2013;8(1-2):136.

4. Reid IR. Fat and bone. Arch Biochem Biophys. 2010;503(1):20-7.

5. Zhao LJ, Jiang H, Papasian CJ, Maulik D, Drees B, Hamilton $\mathrm{J}$, et al. Correlation of obesity and osteoporosis: effect of fat mass on the determination of osteoporosis. J Bone Miner Res. 2008;23(1):17-29.

6. Tang X, Liu G, Kang J, Hou Y, Jiang F, Yuan W, et al. Obesity and risk of hip fracture in adults: a meta-analysis of prospective cohort studies. PloS One. 2013;8(4):e55077.

7. Premaor MO, Pilbrow L, Tonkin C, Parker RA, Compston J. Obesity and fractures in postmenopausal women. $J$ Bone Miner Res. 2010;25(2):292-7.

8. Compston JE, Watts NB, Chapurlat R, Cooper C, Boonen S, Greenspan $S$, et al. Obesity is not protective against fracture in postmenopausal women: GLOW. Am J Med. 2011;124(11):1043-50.

9. Laslett LL, Just Nee Foley SJ, Quinn SJ, Winzenberg TM, Jones G. Excess body fat is associated with higher risk of vertebral deformities in older women but not in men: a cross-sectional study. Osteoporos Int. 2012;23(1):67-74.

10. Nielson $\mathrm{CM}$, Srikanth $\mathrm{P}$, Orwoll ES. Obesity and fracture in men and women: an epidemiologic perspective. $\mathrm{J}$ Bone Miner Res. 2012;27(1):1-10.

11. Premaor MO, Compston JE, Fina Aviles F, Pages-Castella $A$, Nogues $X$, Diez-Perez A, et al. The association between fracture site and obesity in men: a population-based cohort study. J Bone Miner Res. 2013;28(8):1771-7.

12. Prieto-Alhambra D, Premaor MO, Fina Aviles F, Hermosilla E, Martinez-Laguna D, Carbonell-Abella $C$, et al. The association between fracture and obesity is site-dependent: a populationbased study in postmenopausal women. $\mathrm{J}$ Bone Miner Res. 2012;27(2):294-300.

13. Ruosi C, Liccardo S, Rossi D, Colella G, Di Somma C, Colao A. Importance of spinal deformity index in risk evaluation of VCF (vertebral compression fractures) in obese subjects: prospective study. Eur Spine J. 2013;22 Suppl 6:S945-9.

14. Tanaka S, Kuroda T, Saito M, Shiraki M. Overweight/obesity and underweight are both risk factors for osteoporotic fractures at different sites in Japanese postmenopausal women. Osteoporos Int. 2013;24(1):69-76.

15. Ong T, Sahota O, Tan W, Marshall L. A United Kingdom perspective on the relationship between body mass index (BMI) and bone health: a cross sectional analysis of data from the Nottingham Fracture Liaison Service. Bone. 2014;59:207-10.

16. Nielson CM, Marshall LM, Adams AL, LeBlanc ES, Cawthon PM, Ensrud K, et al. BMI and fracture risk in older men: the osteoporotic fractures in men study (MrOS). J Bone Miner Res. 2011;26(3):496-502.

17. Premaor MO, Ensrud K, Lui L, Parker RA, Cauley J, Hillier TA, et al. Risk factors for nonvertebral fracture in obese older women. $J$ Clin Endocrinol Metab. 2011;96(8):2414-21.

18. Armstrong ME, Spencer EA, Cairns BJ, Banks E, Pirie K, Green J, et al. Body mass index and physical activity in relation to the in- 
cidence of hip fracture in postmenopausal women. J Bone Miner Res. 2011;26(6):1330-8.

19. De Laet C, Kanis JA, Oden A, Johanson H, Johnell O, Delmas P, et al. Body mass index as a predictor of fracture risk: a metaanalysis. Osteoporos Int. 2005;16(11):1330-8.

20. Johansson $H$, Kanis JA, Oden A, McCloskey E, Chapurlat RD, Christiansen $\mathrm{C}$, et al. A meta-analysis of the association of fracture risk and body mass index in women. $\mathrm{J}$ Bone Miner Res. 2014;29(1):223-33

21. Compston JE, Flahive J, Hooven FH, Anderson FA Jr, Adachi JD, Boonen S, et al. Obesity, health-care utilization, and health-related quality of life after fracture in postmenopausal women: Global Longitudinal Study of Osteoporosis in Women (GLOW). CalcifTissue Int. 2014;94(2):223-31.

22. Gnudi S, Sitta E, Lisi L. Relationship of body mass index with main limb fragility fractures in postmenopausal women. J Bone Miner Metab. 2009;27(4):479-84.

23. Bouxsein ML, Szulc P, Munoz F, Thrall E, Sornay-Rendu E, Delmas PD. Contribution of trochanteric soft tissues to fall force estimates, the factor of risk, and prediction of hip fracture risk. J Bone Miner Res. 2007;22(6):825-31.

24. Chan BK, Marshall LM, Winters KM, Faulkner KA, Schwartz AV, Orwoll ES. Incident fall risk and physical activity and physical performance among older men: the Osteoporotic Fractures in Men Study. Am J Epidemiol. 2007;165(6):696-703.

25. Corbeil P, Simoneau M, Rancourt D, Tremblay A, Teasdale N. Increased risk for falling associated with obesity: mathematical modeling of postural control. IEEETrans Neural Syst Rehabil Eng. 2001;9(2):126-36.

26. Ensrud KE, Ewing SK, Taylor BC, Fink HA, Cawthon PM, Stone $\mathrm{KL}$, et al. Comparison of 2 frailty indexes for prediction of falls, disability, fractures, and death in older women. Arch Intern Med. 2008;168(4):382-9.

27. Mignardot JB, Olivier I, Promayon E, Nougier V. Obesity impact on the attentional cost for controlling posture. PloS One. 2010;5(12):e14387.

28. Sukumar D, SchlusselY, Riedt CS, Gordon C, StahIT, Shapses SA. Obesity alters cortical and trabecular bone density and geometry in women. Osteoporos Int. 2011;22(2):635-45.

29. Kanis JA on behalf of the World Health Organization Scientific Group (2007) Assessment of osteoporosis at the primary healthcare level. Technical Report. World Health Organization Collaborating Centre for Metabolic Bone Diseases, University of Sheffield, UK. 2007: Printed by the University of Sheffield. Available at: http://www.shef.ac.uk/FRAX/pdfs/WHO_Technical_Report.pdf on February 2014.

30. Kanis JA, McCloskey EV, Johansson H, Oden A, Strom O, Borgstrom F. Development and use of FRAX in osteoporosis. Osteoporos Int. 2010;21 Suppl 2:S407-13.

31. Kanis JA, Oden A, Johansson $H$, Borgstrom F, Strom O, McCloskey E. FRAX and its applications to clinical practice. Bone. 2009;44(5):734-43.

32. Silva HG, Mendonca LM, Conceicao FL, Zahar SE, Farias ML. Influence of obesity on bone density in postmenopausal women. Arq Bras Endocrinol Metabol. 2007;51(6):943-9.

33. Evans EM, Mojtahedi MC, Kessinger RB, Misic MM. Simulated change in body fatness affects Hologic QDR 4500A whole body and central DXA bone measures. J Clin Densitom. 2006;9(3):31522.

34. Yu EW, Bouxsein ML, Roy AE, Baldwin C, Cange A, Neer RM, et al. Bone loss after bariatric surgery: discordant results between DXA and QCT bone density. J Bone Miner Res. 2014;29(3):542-50.

35. Premaor M, Parker RA, Cummings S, Ensrud K, Cauley JA, Lui LY, et al. Predictive value of FRAX for fracture in obese older women. J Bone Miner Res. 2013;28(1):188-95.
36. Barbour KE, Zmuda JM, Boudreau R, Strotmeyer ES, Horwitz $M J$, Evans RW, et al. Adipokines and the risk of fracture in older adults. J Bone Miner Res. 2011;26(7):1568-76.

37. Karsenty G, Ferron M. The contribution of bone to whole-organism physiology. Nature. 2012;481(7381):314-20.

38. Clemens TL, Karsenty G. The osteoblast: an insulin target cell controlling glucose homeostasis. J Bone Miner Res. 2011;26(4):677-80.

39. Kawai M, Rosen CJ. PPARgamma: a circadian transcription factor in adipogenesis and osteogenesis. Nat Rev Endocrinol. 2010;6(11):629-36.

40. Cummings SR, Nevitt MC. Non-skeletal determinants of fractures: the potential importance of the mechanics of falls. Study of Osteoporotic Fractures Research Group. Osteoporos Int. 1994;4 Suppl 1:67-70.

41. Langlois JA, Harris T, Looker AC, Madans J. Weight change between age 50 years and old age is associated with risk of hip fracture in white women aged 67 years and older. Arch Intern Med. 1996;156(9):989-94.

42. Meyer HE,Tverdal A, Selmer R. Weight variability, weight change and the incidence of hip fracture: a prospective study of 39,000 middle-aged Norwegians. Osteoporos Int. 1998;8(4):373-8.

43. Ensrud KE, Ewing SK, Stone KL, Cauley JA, Bowman PJ, Cummings $S R$, et al. Intentional and unintentional weight loss increase bone loss and hip fracture risk in older women. J Am Geriatr Soc. 2003;51(12):1740-7.

44. Silverman NE, Nicklas BJ, Ryan AS. Addition of aerobic exercise to a weight loss program increases BMD, with an associated reduction in inflammation in overweight postmenopausal women. CalcifTissue Int. 2009;84(4):257-65.

45. Villareal DT, Fontana L, Weiss EP, Racette SB, Steger-May K, Schechtman $\mathrm{KB}$, et al. Bone mineral density response to caloric restrictioninduced weight loss or exercise-induced weight loss: a randomized controlled trial. Arch Intern Med. 2006;166(22):2502-10.

46. Shapses SA, Sukumar D. Bone metabolism in obesity and weight loss. Annu Rev Nutr. 2012;32:287-309.

47. Bischoff-Ferrari HA, Dawson-Hughes B, Staehelin HB, Orav JE, Stuck $A E$, Theiler $R$, et al. Fall prevention with supplemental and active forms of vitamin D: a meta-analysis of randomised controlled trials. BMJ. 2009;339:b3692.

48. Lee P, Greenfield JR, Seibel MJ, Eisman JA, Center JR. Adequacy of vitamin $D$ replacement in severe deficiency is dependent on body mass index. Am J Med. 2009;122(11):1056-60.

49. Eastell R, Black DM, Boonen S, Adami S, Felsenberg D, Lippuner $\mathrm{K}$, et al. Effect of once-yearly zoledronic acid five milligrams on fracture risk and change in femoral neck bone mineral density. $\mathrm{J}$ Clin Endocrinol Metab. 2009;94(9):3215-25.

50. McCloskey EV, Johansson H, Oden A, Vasireddy S, Kayan K, Pande $K$, et al.Ten-year fracture probability identifies women who will benefit from clodronate therapy--additional results from a double-blind, placebo-controlled randomised study. Osteoporos Int. 2009;20(5):811-7.

51. McClung MR, Boonen S, Torring $\mathrm{O}$, Roux $\mathrm{C}$, Rizzoli R, Bone HG, et al. Effect of denosumab treatment on the risk of fractures in subgroups of women with postmenopausal osteoporosis. J Bone Miner Res. 2012;27(1):211-8.

52. Baldwin KD, Matuszewski PE, Namdari S, Esterhai JL, Mehta S. Does morbid obesity negatively affect the hospital course of patients undergoing treatment of closed, lower-extremity diaphyseal long-bone fractures? Orthopedics. 2011;34(1):18.

53. Green E, Lubahn JD, Evans J. Risk factors, treatment, and outcomes associated with nonunion of the midshaft humerus fracture. J Surg Orthop Adv. 2005;14(2):64-72.

54. King AR, Moran SL, Steinmann SP. Humeral nonunion. Hand Clin. 2007;23(4):449-56, vi. 
55. Porter SE, Graves ML, Qin Z, Russell GV. Operative experience of pelvic fractures in the obese. Obes Surg. 2008;18(6):702-8.

56. Strauss EJ, Frank JB, Walsh M, Koval KJ, Egol KA. Does obesity influence the outcome after the operative treatment of ankle fractures? J Bone Joint Surg Br. 2007;89(6):794-8.

57. Prieto-Alhambra D, Premaor MO, Aviles FF, Castro AS, Javaid MK, Nogues X, et al. Relationship Between Mortality and BMI After Fracture: A Population-Based Study of Men and Women Aged $\geq 40$ Years. J Bone Miner Res. 2014 Feb 24. doi: 10.1002/jbmr.2209. [Epub ahead of print].

58. Habbu A, Lakkis NM, Dokainish H. The obesity paradox: fact or fiction? Am J Cardiol. 2006;98(7):944-8.

59. Kalantar-Zadeh K, Block G, Horwich T, Fonarow GC. Reverse epidemiology of conventional cardiovascular risk factors in patients with chronic heart failure. J Am Coll Cardiol. 2004;43(8):1439-44.

60. Kalantar-Zadeh K, Block G, Humphreys MH, Kopple JD. Reverse epidemiology of cardiovascular risk factors in maintenance dialysis patients. Kidney Int. 2003;63(3):793-808.

61. Landbo C, Prescott E, Lange P, Vestbo J, AlmdalTP. Prognostic value of nutritional status in chronic obstructive pulmonary disease. Am J Respir Crit Care Med. 1999;160(6):1856-61.
62. Batsis JA, Huddleston JM, Melton LJ 3rd, Huddleston PM, Larson $\mathrm{DR}$, Gullerud RE, et al. Body mass index (BMI) and risk of noncardiac postoperative medical complications in elderly hip fracture patients: a population-based study. J Hosp Med. 2009;4(8):E1-9.

63. Batsis JA, Huddleston JM, Melton LJ 4th, Huddleston PM, LopezJimenez $F$, Larson DR, et al. Body mass index and risk of adverse cardiac events in elderly patients with hip fracture: a populationbased study. J Am Geriatr Soc. 2009;57(3):419-26.

64. King CM, Hamilton GA, Cobb M, Carpenter D, Ford LA. Association between ankle fractures and obesity. J Foot Ankle Surg. 2012;51(5):543-7.

65. Bergkvist D, Hekmat K, Svensson T, Dahlberg L. Obesity in orthopedic patients. Sug Obes Relat Dis. 2009;5(6):670-2.

66. Beck TJ, Petit MA, Wu G, LeBoff MS, Cauley JA, Chen Z. Does obesity really make the femur stronger? BMD, geometry, and fracture incidence in the women's health initiative-observational study. J Bone Miner Res. 2009;24(8):1369-79.

67. Pirro M, Fabbriciani G, Leli C, Callarelli L, Manfredelli MR, Fioroni $C$, et al. High weight or body mass index increase the risk of vertebral fractures in postmenopausal osteoporotic women. J Bone Miner Metab. 2010;28(1):88-93. 